\section{Induced abortion during youth: social inequalities in the outcome of the first pregnancy}

\author{
Aborto provocado na juventude: \\ desigualdades sociais no desfecho \\ da primeira gravidez
}

Greice M. S. Menezes ${ }^{1}$

Estela M. L. Aquino ${ }^{1}$

Diorlene Oliveira da Silva ${ }^{1}$

\author{
1 Instituto de Saúde Coletiva, \\ Universidade Federal da \\ Bahia, Salvador, Brasil. \\ Correspondence \\ G. M. S. Menezes \\ MUSA - Programa Integrado \\ de Pesquisa e Cooperação \\ Técnica em Gênero \\ e Saúde, Instituto de Saúde \\ Coletiva, Universidade \\ Federal da Bahia. \\ Rua Basílio da Gama s/n \\ Campus Universitário \\ do Canela, Salvador, BA \\ 40110-170, Brasil. \\ musa@ufba.br \\ greice@ufba.br
}

\section{Abstract}

This study aimed to identify the factors associated with induced abortion in the first pregnancy in young women and in the first time young men got their partners pregnant. The methodology was a household survey with face-to-face interviews in a probabilistic sample in three stages with 4,634 subjects, aged 18 to 24 years of age residing in the cities of Salvador, Rio de Janeiro, and Porto Alegre, Brazil. Logistic regression analysis was used with a hierarchical strategy for entering variables into the model. Abortion was the reported outcome of the first pregnancy for $16.7 \%$ of the women and $45.9 \%$ of the men (in relation to their partners). Key factors associated with abortion included higher schooling and the occasional nature of the relationship with the male or female partner in the respective pregnancy. Inclusion of males in the study provided new elements for understanding the abortion phenomenon, including in the gender issues in discussion of the theme. The authors recommend greater public investment to warrant access to information and means for young people to achieve their reproductive plans in a security and healthy way, respecting their sexual and reproductive rights.

Induced Abortion; Gender Identity; Sexuality

\section{Introduction}

In Brazil, abortion is still widely used by women as a solution to unplanned pregnancies, especially in settings that hinder access to effective contraceptives. Abortion is a major cause of maternal morbidity and mortality, involving high costs in treatment of its complications 1. Post-abortion curettage is one of the most widely used obstetric procedures in the public healthcare system.

There is a reasonably extensive literature on the theme in Brazil, allowing one to identify the profile of women who report having submitted to induced abortion, the reasons cited, the methods used, and issues pertaining to the decision to abort 2,3 .

Much of the research focuses on specific population groups, mostly women admitted to public hospitals for treatment of incomplete abortion. Such studies thus display a selection bias by including cases with complications and resulting in hospitalization in the public healthcare system. By focusing predominantly on low-income groups, they limit the discussion of the determinants of abortion to the precarious living conditions, overshadowing the heterogeneity of situations actually involved 4,5 .

The male perspective is only rarely considered, and even then by way of indirect information from women interviewees. Few studies directly interview the men themselves 6 , and most adopt a qualitative approach 4 . 
Population-based studies are rare, since they are both expensive and involve difficulties related to abortion's illegality in Brazil and the moral and religious issues surrounding the interruption of a pregnancy, so that information on it is omitted. Several studies 7,8,9 showed underreporting of abortion, highlighting the specific situation of younger women, who resort to the procedure more frequently, are more prone to withhold information 7 , and have the highest proportion of what are considered unwanted pregnancies 9.

The relevance of abortion in youth is also emphasized in other circumstances. In countries in various regions of the world and with different development levels, there is a higher abortion rate among 20-24-year-old women, the period of life in which they are most sexually active, most fertile, and thus most exposed to pregnancy. However, having become pregnant, women under 20 are the most prone to interrupting the pregnancy 10 .

Among women under 25 years of age, the reasons cited for abortion relate to the fact that they feel too young, fear a negative reaction from their parents, lack a consolidated marital relationship, and fear possible interference in their school plans 11,12,13.

An understanding of abortion in youth must consider changes in Western societies, with mass schooling for women, the spread of feminist values, and recourse to effective contraceptives. In this scenario, social norms related to reproduction define a limited number of children as the ideal and the prime moment to have them, thereby qualifying pregnancy in youth (and particularly during adolescence) as inappropriate; pregnancy is thus seen as an obstacle to educational and professional aspirations, especially for young women with greater social and cultural capital 14. In addition, young people's lack of material and financial autonomy and their involvement in as-yet unconsolidated relationships run counter to the dominant representation, valuing the arrival of a child under certain specified conditions 12 .

Abortion thus meets the expectations for controlling procreation in this age bracket, and is therefore more tolerated 12 . Some young people may even be against this practice, but when faced with real-life situations their objections are overshadowed, and recourse to abortion is triggered 5 .

The current study is part of the GRAVAD Research Project (Teenage Pregnancy: A Multicenter Study on Youth, Sexuality, and Reproduction in Brazil) in Salvador, Rio de Janeiro, and Porto Alegre, three Brazilian State capitals that are culturally quite distinct.
The article is intended to identify the factors associated with induced abortion as the outcome of the first pregnancy in Brazilian youth. Inclusion of young men's reports on their partners' pregnancy aimed to give visibility to the male perspective on this issue.

\section{Methodology}

This was a cross-sectional study using a household survey from October 2001 to February 2002, including 18-24-year-olds of both sexes residing in the cities of Porto Alegre, Rio de Janeiro, and Salvador.

By selecting youth from a different age bracket than that traditionally defined as adolescence (10 to 19 years) 15 , the study intended to reconstruct the subjects' life stories, allowing them to identify reproductive events, their outcomes and consequences, while memory were still fresh. Since the youth were already of legal age, no parental authorization was required to participate, thus guaranteeing their decision-making autonomy. For analytical purposes, pregnancy and abortion in adolescence were defined as having occurred before the age of 20, thus allowing comparisons with other studies.

Based on estimates of teenage pregnancy in the Brazilian National Demographic and Health Survey (PNDS 1996), a sample size of 1,500 youth was defined for each city, considering potential losses of $20 \%$, with the allocation of at least 55 census tracts and 33 households per tract. The sample was defined in three stages: in each city, the census tracts were stratified according to mean income and head-of-household's schooling, and in each stratum, tracts were selected with probabilities proportional to the number of 18-24-year-olds based on the population count (1996); in each tract, the permanent private households which had members in the target age bracket were selected, 33 were chosen for interviews; in each household, an eligible individual was chosen whose birthday was the first in order in the calendar year, regardless of the year of birth.

A total of 4,634 subjects were interviewed, with high response rates $(85.2 \%)$ and low proportions of losses and refusals. The most common sources of losses were closed households (6.1\%), especially in what were considered unsafe neighborhoods, and absence of the selected subjects, i.e., who were away from the household at the time (3.9\%). There were also few refusals, having occurred mostly at the young person's initiative $(3.8 \%)$ or that of third par- 
ties, impeding access to them by the interviewers $(0.2 \%)$. The interviewees' age and gender profile was quite similar to that in the 2000 population census, conducted in temporal proximity to the survey 16 .

The face-to-face interview used a structured questionnaire with closed questions, covering common indicators in male and female versions, with the languages adapted to the respective sex. It included questions on socio-demographic information, affective and sexual histories, schooling and work, and attitudes and values related to sexuality, and pregnancy, their developments and outcomes. The abortion issue was approached at different moments in the interview, with a question on the occurrence of pregnancy and its outcome in distinct relationships. The young men were also asked about pregnancy in their female partners.

Quality control was ensured by doublechecking the questions in a $20 \%$ sub-sample of interviews, using a new personal or telephone contact by a different interviewer.

The database was built using independent double keying-in with Epi Info version 6.04b (Centers for Disease Control and Prevention, Atlanta, USA) and was exported to Stata version 8.0 (Stata Corporation, College Station, USA), which allows incorporating the sample design effect and relative weights for each unit when estimating the parameters.

For analytical purposes, the dependent variable was proportion of induced abortions in first pregnancy, excluding subjects who reported spontaneous abortion as the outcome $(8.7 \%$ of females and $17.7 \%$ of males) or whose own gestation (or that of the male interviewee's partner) was under way at the time of the interview (5.3 and 5.6\%, respectively). For this variable only, the data were presented separately for each of the three cities and were subsequently aggregated due to the small number, which would have prevented stratified analyses.

Bivariate analyses were performed to identify the factors associated with induced abortion as the outcome of the first pregnancy. An indicator of school mobility 16 was constructed based on the mother's and the youth's own schooling, with the following categories: both the youth and mother with a secondary or university education; both with primary education; upward mobility (the young person with secondary or university education and the mother with primary); and downward mobility (the young person with primary education and the mother with secondary or university). As for age at sexual debut, different cutoff points were used for males $(<16-17$ years versus old- er) and females ( $<17-18$ years versus older), in light of gender differences, given that this event occurs earlier and is more homogeneous in males.

Differences between proportions were tested for statistical significance using the Pearson $\chi^{2}$, with a second-order Rao \& Scott correction, at the $5 \%$ level.

The magnitude of the association was estimated between the target outcome and selected factors using odds ratios (OR) and respective $95 \%$ confidence intervals $(95 \% \mathrm{CI})$.

Unconditional logistic regression was also performed, selecting the variables associated with induced abortion in the bivariate stage, with a p-value of 0.20 or less. Except for "religion during upbringing", which remained as a dummy, all the others were dichotomized to guarantee a sufficient number of cases when distributed in the strata. The indicator "school mobility" was not included in the regression model due to the overlapping of information with the young person's own schooling.

A hierarchical, forward-type strategy was used to enter the variables into the model, with progressive introduction in a four-section theoretical model for an understanding of the processes determining the pregnancy outcome. Based on Bajos \& Marquet 17, this model prioritizes the phenomenon's macro-social determination, assuming mediation by factors in the affective and sexual history and a more immediate impact from the interactional context, that is, elements from the relationship with the partner in this index pregnancy and the young person's individual characteristics at the time of the event (Figure 1).

The variables whose association with abortion had p-values less than $10 \%$ were kept in the model. After selecting the family/social variables, the subsequent sections were introduced progressively, removing those not associated with the outcome, after adjusting for variables from the same section or those hierarchically superior. At each stage, the variables associated with the outcome were kept, even when losing statistical significance with the inclusion of each new section. The final model considered a p-value of less than $5 \%$ to indicate a statistically significant association.

The study was approved by the Institutional Review Boards/Research Ethics Committees of the respective academic centers, having ensured anonymity, confidentiality of answers, and freedom to refuse to participate and to interrupt the interview. The participants signed an informed consent form. 
Hierarchical model for analyzing determination of induced abortion in the first pregnancy, 18-24-year-olds, Porto Alegre, Rio de Janeiro, Salvador, Brazil.

\section{Social/Family}

Mode of sexual debut

Interaction with partner in pregnancy

Situation at time of pregnancy
Monthly per capita family income

Religion of upbringing

Mother's age at first child

Young person's schooling

Talked with parents about pregnancy

and contraceptives

Experiences in affective history

Age at sexual debut

Type of partnership in sexual debut

Age difference between partners

Type of partnership

Couple's intentions as to relationship

Couple's prior intentions and attitudes

towards the pregnancy

Age at time

Studying at time

Working at time

INDUCED ABORTION IN FIRST PREGNANCY

Source: GRAVAD Research Project, 2002.

\section{Results}

\section{Induced abortion as outcome of first pregnancy}

Specifically considering the females' own first pregnancy (740 cases) and the first time the males got a partner pregnant (427 cases), induced abortion was the reported outcome for $16.7 \%$ of females and $45.9 \%$ of males, so the birth of a child was the most frequent result for both sex.

The highest proportions of induced abortion in the first pregnancy were reported by males (in relation to their partners) in Porto Alegre (31.1\%), Rio de Janeiro (39.5\%), and Salvador $(60.7 \%)$; in the latter city, abortion was thus more frequent than the birth of a child. Among females, the proportion of induced abortions in the first pregnancy was also higher in Salvador (19\%) than in Rio de Janeiro (17\%) and Porto Alegre (8.4\%) (Figure 2).

\section{Women's experience with induced abortion}

Family income and schooling were associated with abortion, which was almost four times as frequent in girls with a monthly family income greater than R\$180.00 (approximately U\$90) and three times as frequent in those with more schooling, as compared to those with lower family incomes and less schooling (Table 1).

Frequency of abortion in young women with upward schooling mobility, i.e., who had more 
schooling than their mothers, was almost three times greater than in those who maintained the same low level of schooling as their mothers. This pattern was similar to that shown in the group of women and mothers with secondary or university education (Table 1), although girls with upward school mobility do not appear to have had access to the same conditions for performing abortion as reported by women who had secondary/university education like their mothers. Thus, young women with upward school mobility admitted to having submitted to more abortions after the first trimester of pregnancy (29.5\% versus $19.3 \%$ ), having resorted less to clinics or private medical offices ( $40.5 \%$ versus $61.4 \%$ ), having used misoprostol (Cytotec $\left.{ }^{\circledR}\right)(52.6 \%$ versus $33.8 \%)$, and having used vacuum procedures less frequently ( $17.4 \%$ versus $38 \%$ ) (data not shown).

The girl's mother's age at first child was also associated with abortion in the first pregnancy. For women whose mothers experienced motherhood for the first time after 19 years of age, the proportion of abortions in their first reproductive episodes was more than double that of girls whose mothers had their first child during adolescence (Table 1). Neither self-reported race/ color nor parents' separation was statistically associated with the target event (data not shown).

Among women whose sexual debut was with an occasional partner, $35.8 \%$ reported abortion in the first pregnancy, and this outcome was twice as common in this group as compared to those who had debuted with a steady partner. Abortion was also four times as common among women who reported having experienced both ficar (making out) and dating as compared to those who had experienced only dating $(20.5 \%$ versus $5.9 \%$ ) (Table 1 ).

Among the factors related to interaction with the partner in the first pregnancy, abortion was twice as common in non-stable relationships or those in crisis (didn't intend to marry or live together, wasn't thinking about the future, intended to end the relationship), as compared to those within an existing or planned marital union (was already married or wanted to marry/live with the partner). When the woman reported that she had not wanted to get pregnant and was using a contraceptive method to avoid it, abortion was the outcome of the pregnancy in $26.7 \%$ of cases, contrary to other situations (15.2\%) (trying to get pregnant, wanted to get pregnant later, wasn't thinking about it, regardless of using contraceptives) (Table 1 ).

As for the girl's situation at the time of the pregnancy, concurrent school enrolment was the only factor associated with abortion, which
Figure 2

Outcome of first pregnancy according to sex and city in 18-24-year-olds.

Porto Alegre, Rio de Janeiro, and Salvador, Brazil.

\begin{tabular}{|c|c|c|c|}
\hline & & Birth of a child & Abortion \\
\hline \multirow{3}{*}{$\begin{array}{l}\text { Women } \\
(p=0.1629)\end{array}$} & \multirow{3}{*}{$\begin{array}{l}\text { Porto Alegre }(n=191) \\
\text { Rio de Janeiro }(n=235) \\
\text { Salvador }(n=314)\end{array}$} & $91.6 \%$ & $8.4 \%$ \\
\hline & & $83.0 \%$ & $17.0 \%$ \\
\hline & & $81.0 \%$ & $19.0 \%$ \\
\hline \multirow{3}{*}{$\begin{array}{l}\text { Men } \\
(p=0.0006)\end{array}$} & \multirow{3}{*}{$\begin{array}{l}\text { Porto Alegre }(n=126) \\
\text { Rio de Janeiro }(n=137) \\
\text { Salvador }(n=164)\end{array}$} & $68.9 \%$ & $31.1 \%$ \\
\hline & & $60.5 \%$ & $39.5 \%$ \\
\hline & & $39.3 \%$ & $60.7 \%$ \\
\hline
\end{tabular}

Source: GRAVAD Research Project, 2002.

was almost five times more common as compared to girls not in school. Neither being an adolescent nor working at the time was associated with abortion (Table 1).

At the first level of logistic regression, family income and schooling were strongly associated with abortion in the first pregnancy, even after adjusting for the factors in this section and the following. The variable "mother's age at first child" lost significance after adjusting for other factors at this level. At the second level, related to sexual debut, only having experienced both one-night stands and steady dating remained in the model (Table 2).

At the third level, related to interaction with the partner in the first pregnancy, not intending to continue the relationship with the partner was associated with abortion after adjusting for other factors in this section and the next, although with a slight decrease in the effect. At the fourth and last level, no variable pertaining to the girl's situation at the time of the pregnancy remained in the model (Table 2).

In short, for women, having a secondary or university education, belonging to middle or upper-class families, having an affective/sexual history including both ficar (making out) and dating, and not having a steady relationship with the male partner in the first pregnancy were associated with increased probability of abortion (Figure 3).

\section{The male perspective towards the partner's pregnancy}

As observed in females, males' level of schooling was associated with the outcome of pregnancy in their partners. Among those who had 
Factors associated with induced abortion in the first pregnancy in women and in the first time men got their partners pregnant. 18-24-year-olds in Porto Alegre, Rio de Janeiro, and Salvador, Brazil.

\begin{tabular}{|c|c|c|c|c|c|c|}
\hline \multirow[t]{3}{*}{ Factors } & \multicolumn{6}{|c|}{ Reported abortion } \\
\hline & \multicolumn{3}{|c|}{ Females } & \multicolumn{3}{|c|}{ Males } \\
\hline & $\mathrm{n}$ & $\%$ & $\mathrm{p}$ & $\mathrm{n}$ & $\%$ & $p$ \\
\hline \multicolumn{7}{|l|}{ Social/Family } \\
\hline \multicolumn{7}{|l|}{ Monthly per capita family income } \\
\hline$\leq \mathrm{R} \$ 180.00^{*}$ & 451 & 8.3 & 0.0000 & 192 & 41.3 & 0.1652 \\
\hline$\geq \mathrm{R} \$ 181.00$ & 289 & 29.3 & & 235 & 50.0 & \\
\hline \multicolumn{7}{|l|}{ Schooling } \\
\hline$\leq$ Complete primary & 513 & 10.2 & 0.0000 & 305 & 41.3 & 0.0153 \\
\hline Secondary or university (incomplete or complete) & 210 & 30.2 & & 118 & 61.6 & \\
\hline \multicolumn{7}{|l|}{ School mobility } \\
\hline Young person and mother $\leq$ complete primary & 457 & 9.5 & 0.0000 & 256 & 40.5 & 0.0837 \\
\hline Upward school mobility & 123 & 25.6 & & 47 & 65.6 & \\
\hline Downward school mobility & 52 & 17.7 & & 47 & 44.2 & \\
\hline $\begin{array}{l}\text { Young person and mother with secondary } \\
\text { or university education }\end{array}$ & 85 & 38.7 & & 71 & 57.7 & \\
\hline \multicolumn{7}{|l|}{ Religion of upbringing } \\
\hline Pentecostal & 68 & 7.0 & 0.1159 & 37 & 21.8 & 0.0655 \\
\hline Catholic & 515 & 19.6 & & 265 & 46.4 & \\
\hline Other & 73 & 15.0 & & 57 & 42.1 & \\
\hline None & 78 & 9.2 & & 65 & 54.3 & \\
\hline \multicolumn{7}{|l|}{ Mother's age at first child (years) } \\
\hline$\leq 19$ & 415 & 11.0 & 0.0001 & 218 & 47.7 & 0.6415 \\
\hline$\geq 20$ & 324 & 23.1 & & 204 & 44.5 & \\
\hline \multicolumn{7}{|l|}{ Sexual initiation } \\
\hline \multicolumn{7}{|l|}{$\begin{array}{l}\text { Talked with father or mother about } \\
\text { pregnancy and contraceptive methods }\end{array}$} \\
\hline Yes & 263 & 12.5 & 0.1444 & 179 & 45.1 & 0.9542 \\
\hline No & 476 & 19.2 & & 244 & 45.6 & \\
\hline \multicolumn{7}{|l|}{ Experiences in affective history } \\
\hline Only dating & 217 & 5.9 & 0.0011 & 26 & 28.8 & 0.2088 \\
\hline Ficar (making out) ${ }^{\star \star}$ and dating & 522 & 20.5 & & 400 & 47.1 & \\
\hline \multicolumn{7}{|l|}{ Age at sexual debut } \\
\hline Earlier ${ }^{\star \star \star}$ & 584 & 18.2 & 0.1402 & 332 & 45.1 & 0.7918 \\
\hline Later\# & 154 & 11.9 & & 94 & 47.1 & \\
\hline \multicolumn{7}{|l|}{ Nature of relationship with partner in sexual debut } \\
\hline Occasional & 70 & 35.8 & 0.0008 & 192 & 55.3 & 0.0116 \\
\hline Steady\#\# & 669 & 15.0 & & 234 & 39.0 & \\
\hline
\end{tabular}

(continues) 


\begin{tabular}{|c|c|c|c|c|c|c|}
\hline \multirow[t]{3}{*}{ Factors } & \multicolumn{6}{|c|}{ Reported abortion } \\
\hline & \multicolumn{3}{|c|}{ Females } & \multicolumn{3}{|c|}{ Males } \\
\hline & $\mathrm{n}$ & $\%$ & $p$ & $\mathrm{n}$ & $\%$ & $p$ \\
\hline \multicolumn{7}{|l|}{ Interaction with partner in first pregnancy } \\
\hline \multicolumn{7}{|l|}{ Prior intentions as to relationship } \\
\hline $\begin{array}{l}\text { To marry or live with or was already married } \\
\text { or lived with partner }\end{array}$ & 453 & 12.4 & 0.0019 & 156 & 36.1 & 0.0228 \\
\hline $\begin{array}{l}\text { Did not intend to marry or live with, or wanted to } \\
\text { end relationship, or was not thinking about the future }\end{array}$ & 283 & 23.4 & & 270 & 51.6 & \\
\hline \multicolumn{7}{|l|}{ Nature of relationship } \\
\hline Occasional & 21 & 34.8 & 0.0428 & 53 & 82.1 & 0.0000 \\
\hline Steady\#\#\# & 712 & 16.1 & & 367 & 39.7 & \\
\hline \multicolumn{7}{|l|}{ Age difference of partner } \\
\hline Partner younger or up to a year older & 147 & 11.2 & 0.0918 & 313 & 42.0 & 0.0249 \\
\hline Partner at least two years older & 575 & 18.2 & & 107 & 59.8 & \\
\hline \multicolumn{7}{|l|}{ Prior intentions and attitude towards the pregnancy } \\
\hline $\begin{array}{l}\text { Did not want to get pregnant and } \\
\text { was using contraceptives }\end{array}$ & 90 & 26.7 & 0.0121 & 333 & 43.5 & 0.1100 \\
\hline Other situations§ & 645 & 15.2 & & 93 & 55.1 & \\
\hline \multicolumn{7}{|l|}{ Situation at time of pregnancy } \\
\hline \multicolumn{7}{|l|}{ Age at time (years) } \\
\hline$\leq 19$ & 601 & 17.5 & 0.3183 & 293 & 54.5 & 0.0001 \\
\hline$\geq 20$ & 138 & 12.8 & & 133 & 28.7 & \\
\hline \multicolumn{7}{|l|}{ Studying at the time } \\
\hline Yes & 571 & 19.6 & 0.0046 & 304 & 49.1 & 0.2080 \\
\hline No & 161 & 4.4 & & 119 & 38.3 & \\
\hline \multicolumn{7}{|l|}{ Working at the time } \\
\hline Yes & 466 & 16.6 & 0.9807 & 353 & 43.0 & 0.0450 \\
\hline No & 272 & 16.5 & & 70 & 63.5 & \\
\hline
\end{tabular}

Source: GRAVAD Research Project, 2002.

* Prevailing minimum wage at the time of the survey.

** Relation without commitment including sex or not.

$\star * *$ Females $\leq 17$ years of age and males $\leq 16$ years.

\# Females $\geq 18$ years and males $\geq 17$ years.

\#\# Includes partners like boyfriend/girlfriend, spouse, companion, and other non-occasional.

\#\#\# Includes partners like that of sexual debut, first boyfriend/girlfriend, other steady, and current partner.

$\S$ Includes was attempting to get pregnant, wanted to get pregnant later, was not thinking

about the matter, regardless of contraceptive use.

studied beyond primary school, abortion was the most common outcome $(61.6 \%)$ and was more common than for males with less schooling (Table 1). This trend is similar to that of young males with upward school mobility, $65.6 \%$ of whom reported abortion the first time they got their partners pregnant, a higher percentage than for boys whose schooling was as low as that of their mothers or those with downward school mobility (Table 1).

Unlike for females, "religion of upbringing" showed an association with abortion, with the outcome more frequent among those brought up in Catholic families (46.4\%) or without any religion $(54.3 \%)$, as compared to those from Pentecostal families (Table 1).

Neither self-defined race/color nor parents' separation influenced the occurrence of abortion when the males' partners became pregnant (data not shown).

The results showed an association between having their sexual debut with an occasional partner and abortion as the outcome of the first time they got their partners pregnant; this result was more frequent than for boys with steady partners (Table 1).

Abortion was reported in the vast majority of pregnancies with occasional partners and 
Hierarchical logistic regression analysis of factors associated with induced abortion in first pregnancy for women 18-24 years old, in Porto Alegre, Rio de Janeiro, and Salvador, Brazil.

\begin{tabular}{|c|c|c|c|c|c|}
\hline \multirow[t]{2}{*}{ Factors } & \multirow{2}{*}{ Crude } & \multicolumn{4}{|c|}{$\begin{array}{l}\text { OR } 95 \% \mathrm{Cl} \\
\text { Adjusted }\end{array}$} \\
\hline & & Level I* & Level II** & Level III & Level IV\# \\
\hline \multicolumn{6}{|l|}{ Social/family } \\
\hline \multicolumn{6}{|l|}{ Monthly per capita family income } \\
\hline$\leq \mathrm{R} \$ 180.00 \# \#$ & 1.0\#\#\# & 1.0\#\#\# & 1.0\#\#\# & 1.0\#\#\# & 1.0\#\#\# \\
\hline$\geq \mathrm{R} \$ 181.00$ & $4.6(2.6-8.2)$ & $3.8(2.0-7.1)$ & $3.6(2.0-6.6)$ & $4.2(2.2-8.1)$ & $4.5(2.3-8.7)$ \\
\hline \multicolumn{6}{|l|}{ Schooling } \\
\hline$\leq$ Complete primary & 1.0\#\#\# & 1.0\#\#\# & 1.0\#\#\# & 1.0\#\#\# & 1.0\#\#\# \\
\hline $\begin{array}{l}\text { Secondary or university } \\
\text { (incomplete or complete) }\end{array}$ & $3.8(2.1-6.8)$ & $2.4(1.3-4.2)$ & $2.9(1.7-5.1)$ & $2.8(1.5-5.1)$ & $2.2(1.2-4.0)$ \\
\hline \multicolumn{6}{|l|}{ Religion of upbringing } \\
\hline Pentecostal & $1.0 \# \#$ & $1.0 \# \#$ & & & \\
\hline Catholic & $3.2(0.9-11.9)$ & $2.1(0.5-8.4)$ & & & \\
\hline Other & $2.3(0.5-11.0)$ & $1.3(0.2-6.9)$ & & & \\
\hline None & $1.3(0.3-5.8)$ & $1.8(0.4-9.1)$ & & & \\
\hline \multicolumn{6}{|l|}{ Mother's age at first child (years) } \\
\hline$\leq 19$ & $1.0 \# \#$ & 1.0\#\#\# & & & \\
\hline$\geq 20$ & $2.4(1.5-3.8)$ & $1.5(0.9-2.6)$ & & & \\
\hline \multicolumn{6}{|l|}{ Sexual initiation } \\
\hline \multicolumn{6}{|l|}{$\begin{array}{l}\text { Talked with father or mother about } \\
\text { pregnancy and contraceptive methods }\end{array}$} \\
\hline Yes & $1.0 \# \#$ & & 1.0\#\#\# & & \\
\hline No & $1.7(0.8-3.4)$ & & $1.5(0.7-3.3)$ & & \\
\hline \multicolumn{6}{|l|}{ Experiences in affective history } \\
\hline Only dating & $1.0 \# \#$ & & $1.0 \# \#$ & $1.0 \# \#$ & $1.0 \# \#$ \\
\hline Ficar (making out)§ and dating & $4.1(1.7-10.1)$ & & $2.8(1.1-7.1)$ & $2.6(1.0-6.7)$ & $2.7(1.1-6.7)$ \\
\hline \multicolumn{6}{|l|}{ Age at sexual debut (years) } \\
\hline$\leq 17$ & $1.6(0.8-3.2)$ & & $2.0(1.0-4.2)$ & $1.9(0.9-4.1)$ & $1.7(0.6-4.4)$ \\
\hline$\geq 18$ & $1.0 \# \#$ & & $1.0 \# \#$ & 1.0\#\#\# & $1.0 \# \#$ \\
\hline \multicolumn{6}{|l|}{$\begin{array}{l}\text { Nature of relationship with partner } \\
\text { in sexual debut }\end{array}$} \\
\hline Occasional & $3.2(1.6-6.4)$ & & $2.0(0.9-4.4)$ & $1.6(0.7-3.9)$ & $1.8(0.8-4.2)$ \\
\hline Steady§§ & $1.0 \# \#$ & & 1.0\#\#\# & $1.0 \# \#$ & 1.0\#\#\# \\
\hline \multicolumn{6}{|l|}{ Interaction with partner in first pregnancy } \\
\hline \multicolumn{6}{|l|}{ Prior intentions as to relationship } \\
\hline $\begin{array}{l}\text { To marry or live with or was already } \\
\text { married or lived with partner }\end{array}$ & $1.0 \# \#$ & & & $1.0 \# \#$ & $1.0 \# \#$ \\
\hline $\begin{array}{l}\text { Did not intend to marry or live with, } \\
\text { or wanted to end relationship, or was } \\
\text { not thinking about the future }\end{array}$ & $2.2(1.3-3.5)$ & & & $2.2(1.2-3.8)$ & $1.9(1.1-3.5)$ \\
\hline \multicolumn{6}{|l|}{ Nature of relationship } \\
\hline Occasional & $2.8(1.0-7.8)$ & & & $4.8(1.1-19.9)$ & $3.0(0.8-11.5)$ \\
\hline Steady§§§ & 1.0\#\#\# & & & $1.0 \# \# \#$ & 1.0\#\#\# \\
\hline
\end{tabular}




\begin{tabular}{|c|c|c|c|c|c|}
\hline \multirow[t]{3}{*}{ Factors } & \multicolumn{5}{|c|}{ OR $95 \% \mathrm{Cl}$} \\
\hline & \multirow[t]{2}{*}{ Crude } & \multicolumn{3}{|c|}{ Adjusted } & \multirow[b]{2}{*}{ Level IV\# } \\
\hline & & Level I* & Level II** & 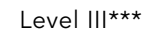 & \\
\hline \multicolumn{6}{|l|}{ Age difference of partner } \\
\hline Partner younger or up to a year older & 1.0\#\#\# & & & $1.0 \# \#$ & \\
\hline Partner at least two years older & $1.8(0.9-3.5)$ & & & $1.7(0.7-3.9)$ & \\
\hline \multicolumn{6}{|l|}{$\begin{array}{l}\text { Prior intentions and attitude } \\
\text { as to the pregnancy }\end{array}$} \\
\hline $\begin{array}{l}\text { Did not want to get pregnant } \\
\text { and were using contraceptives }\end{array}$ & $2.0(1.2-3.6)$ & & & $2.1(0.9-4.6)$ & $1.8(0.7-4.2)$ \\
\hline Other situations ${ }^{\dagger}$ & 1.0\#\# & & & 1.0\#\# & $1.0 \# \#$ \\
\hline \multicolumn{6}{|l|}{ Situation at time of pregnancy } \\
\hline \multicolumn{6}{|l|}{ Age at time (years) } \\
\hline$\leq 19$ & $1.4(0.7-3.0)$ & & & & $1.2(0.4-3.6)$ \\
\hline$\geq 20$ & $1.0 \# \#$ & & & & $1.0 \# \#$ \\
\hline \multicolumn{6}{|l|}{ Studying at the time } \\
\hline Yes & $5.3(1.5-18.6)$ & & & & $2.9(0.8-10.4)$ \\
\hline No & 1.0\#\# & & & & $1.0 \# \#$ \\
\hline \multicolumn{6}{|l|}{ Working at the time } \\
\hline Yes & 1.0 & & & & 1.0 \\
\hline No & $1.0(0.6-1.6)$ & & & & $1.0(0.6-1.8)$ \\
\hline
\end{tabular}

Source: GRAVAD Research Project, 2002.

* For social/family variables.

** For social/family variables selected at the level and for variables related to mode of sexual debut.

$\star * \star$ For variables selected at levels I and II and for variables related to interaction between partners.

\# For variables selected at levels I, II, and III and for variables related to the young person's situation

at the time of the pregnancy.

\#\# Prevailing minimum wage at the time of the survey.

\#\#\# Reference group.

$\S$ Relation without commitment including sex or not.

$\S \S$ Includes partners like boyfriend, spouse, companion, and other non-occasional.

$\S \S \S$ Includes partners like that of sexual debut, first boyfriend, other steady, and current partner.

+ Includes was attempting to get pregnant, wanted to get pregnant later, was not thinking

about the matter, regardless of contraceptive use.

was more frequent than when there was already a steady relationship with the partner. When the pregnancies occurred in women at least two years older than the males, $59.8 \%$ of the cases ended in abortion; this outcome was more common than when the female partner was younger or just slightly older (Table 1).

Among boys, being an adolescent at the time of the partner's pregnancy was associated with abortion, occuring three times more often than for males aged 20 years or older. Among those who reported not working at the time, abortion was twice as frequent, although with borderline statistical significance (Table 1).

In the multivariate analysis, of the family/ social factors that were investigated, schooling and religion of upbringing remained associated with reported abortion in the partner's pregnancy, even adjusting for the variables at this level and the subsequent levels, with little reduction in the magnitude of the effect. No second-level variable (relating to sexual debut) remained in the model after adjusting for variables from the subsequent levels. At the third level, the type of relationship in the pregnancy and the age difference between the partners were associated with abortion, but only the former remained in the model after adjusting for the other variables. At the last level, only the young male's age at the time of the pregnancy remained in the final model (Table 3).

In short, for males, abortion as the outcome of the first time when they got their partners pregnant was associated with the fact that they were adolescents, had more schooling, were brought up without a religion, and the fact that the pregnancy occurred with an occasional partner (Figure 3). 
Figure 3

Final hierarchical logistic regression model for determinants of induced abortion in first pregnancy for females and males (in relation to female partners). Youth 18 to 24 years of age in Porto Alegre, Rio de Janeiro, and Salvador, Brazil.

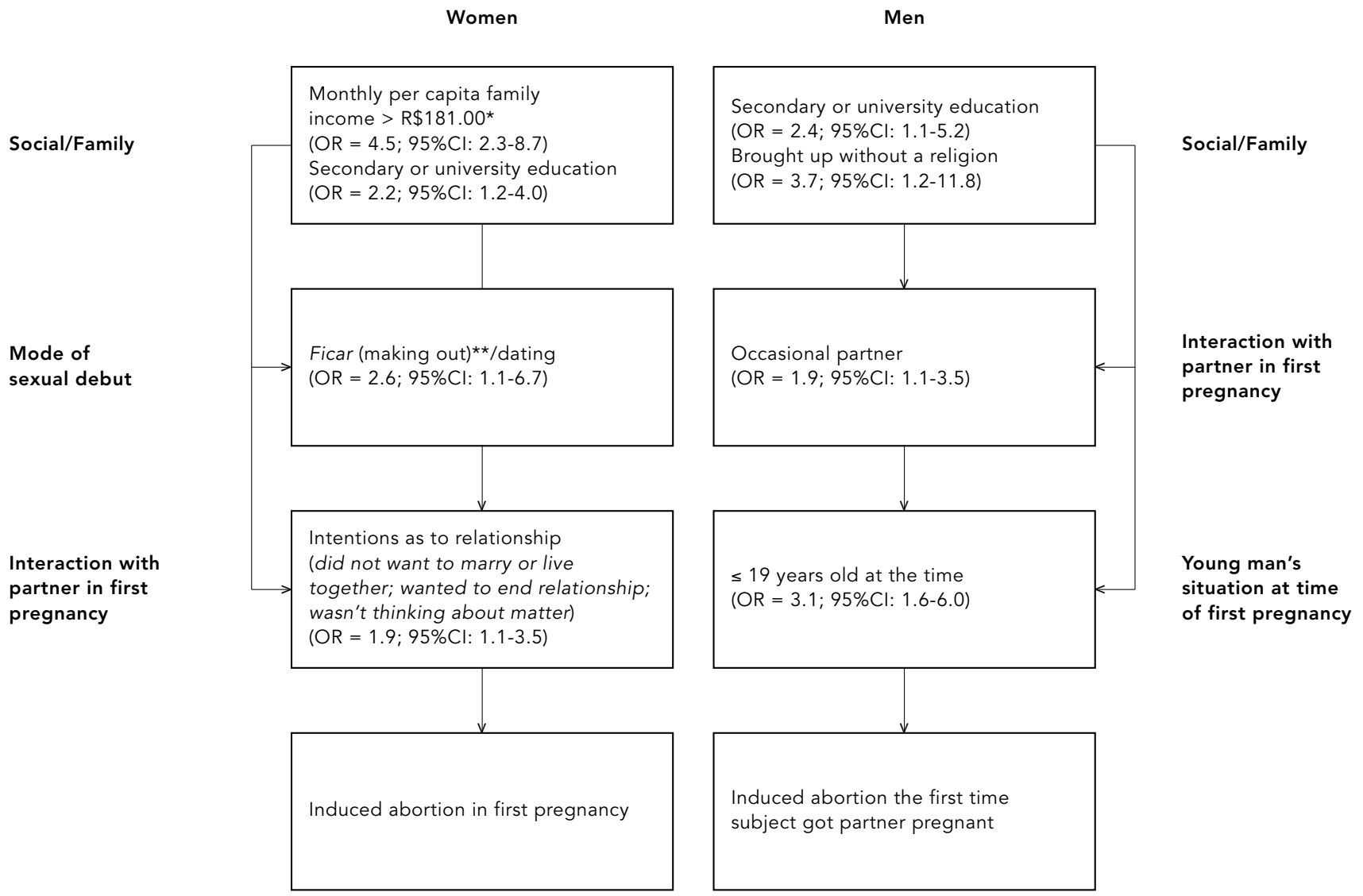

Source: GRAVAD Research Project, 2002.

* Prevailing minimum wage at time of survey.

** Relation without commitment including sex or not.

\section{Discussion}

Abortion in youth is a difficult issue to admit, when it is shrouded in moral and religious questions and where, as in Brazil, it is illegal. The current study was not intended to validate information on abortion, a topic covered by other studies mentioned above, but to expand the analysis of the theme, covering aspects that had received little previous attention.

Various procedures were adopted to favor reporting of abortion by the young subjects, both in preparing the questionnaire, selecting and training interviewers, and procedures adopted during the interview itself 16 . However, such measures do not rule out a discussion of the data output or results.
As for potential selection biases, the criterion for identifying the interviewee among the candidates helped minimize such bias by preventing the interviewer from selecting the young subjects most available for interviewing. Compared to similar surveys, the GRAVAD Research Project had a high response rate $(85.2 \%)$, with low percentages of losses and refusals 16 . It is impossible to totally rule out that the few young people who were not located are those with the greatest probability of having had a pregnancy and abortion. However, if this bias did occur, it probably had a small impact, and in the direction of underestimating the phenomenon.

Since this was a cross-sectional study, it excluded women who died of complications of 
Hierarchical logistic regression analysis of factors associated with induced abortion for first time young men got their partners pregnant, interviewees 18-24 years old, in Porto Alegre, Rio de Janeiro, and Salvador, Brazil.

\begin{tabular}{|c|c|c|c|c|c|}
\hline \multirow[t]{3}{*}{ Factors } & \multicolumn{5}{|c|}{ OR $(95 \% \mathrm{Cl})$} \\
\hline & \multirow{2}{*}{ Crude } & \multicolumn{4}{|c|}{ Adjusted } \\
\hline & & Level I* & Level II** & Level III*** & Level IV\# \\
\hline \multicolumn{6}{|l|}{ Social/Family } \\
\hline \multicolumn{6}{|l|}{ Monthly per capita family income } \\
\hline$\leq \mathrm{R} \$ 180.00 \# \#$ & 1.0\#\#\# & $1.0 \# \#$ & & & \\
\hline$\geq \mathrm{R} \$ 181.00$ & $1.4(0.9-2.3)$ & $1.1(0.6-2.0)$ & & & \\
\hline \multicolumn{6}{|l|}{ Schooling } \\
\hline$\leq$ Complete primary & 1.0\#\#\# & 1.0\#\#\# & $1.0 \# \#$ & 1.0\#\#\# & $1.0 \# \#$ \\
\hline $\begin{array}{l}\text { Secondary or university } \\
\text { (incomplete or complete) }\end{array}$ & $2.3(1.2-4.5)$ & $2.5(1.3-4.9)$ & $2.1(1.1-4.1)$ & $2.0(1.0-3.8)$ & $2.4(1.1-5.2)$ \\
\hline \multicolumn{6}{|l|}{ Religion of upbringing } \\
\hline Pentecostal & $1.0 \# \#$ & $1.0 \# \#$ & $1.0 \# \#$ & $1.0 \# \#$ & $1.0 \# \#$ \\
\hline Catholic & $3.1(1.3-7.3)$ & $2.9(1.2-7.0)$ & $2.2(1.0-5.1)$ & $2.3(0.9-5.8)$ & $1.9(0.7-4.9)$ \\
\hline Other & $2.6(0.7-10.2)$ & $2.5(0.6-10.4)$ & $2.2(0.6-7.4)$ & $2.3(0.6-9.1)$ & $2.3(0.6-9.7)$ \\
\hline None & $4.3(1.5-12.2)$ & $4.4(1.5-13.5)$ & $4.1(1.5-11.3)$ & $4.2(1.3-13.8)$ & $3.7(1.2-11.8)$ \\
\hline \multicolumn{6}{|l|}{ Mother's age at first child (years) } \\
\hline$\leq 19$ & 1.0\#\#\# & $1.0 \# \#$ & & & \\
\hline$\geq 20$ & $0.9(0.5-1.5)$ & $0.7(0.4-1.4)$ & & & \\
\hline \multicolumn{6}{|l|}{ Sexual initiation } \\
\hline \multicolumn{6}{|l|}{$\begin{array}{l}\text { Talked with father or mother about } \\
\text { pregnancy and contraceptive methods }\end{array}$} \\
\hline Yes & 1.0\#\#\# & & $1.0 \# \#$ & & \\
\hline No & $1.0(0.6-1.9)$ & & $1.3(0.7-2.2)$ & & \\
\hline \multicolumn{6}{|l|}{ Experiences in affective history } \\
\hline Only dating & $1.0 \# \#$ & & $1.0 \# \#$ & $1.0 \# \#$ & $1.0 \# \#$ \\
\hline Ficar (making out) and dating & $2.2(0.6-7.7)$ & & $3.5(1.0-12.6)$ & $1.5(0.5-4.6)$ & $1.4(0.5-4.4)$ \\
\hline \multicolumn{6}{|l|}{ Age at sexual debut (years) } \\
\hline$\leq 16$ & $0.9(0.5-1.7)$ & & $0.9(0.5-1.8)$ & & \\
\hline$\geq 17$ & 1.0\#\#\# & & $1.0 \# \#$ & & \\
\hline \multicolumn{6}{|l|}{$\begin{array}{l}\text { Nature of relationship with partner } \\
\text { in first pregnancy }\end{array}$} \\
\hline Occasional & $1.9(1.2-3.2)$ & & $1.8(1.1-3.1)$ & $1.7(1.0-3.0)$ & $1.8(1.0-3.2)$ \\
\hline Steady§ & $1.0 \# \#$ & & $1.0 \# \#$ & $1.0 \# \#$ & $1.0 \# \#$ \\
\hline \multicolumn{6}{|l|}{$\begin{array}{l}\text { Interaction with partner } \\
\text { in first pregnancy }\end{array}$} \\
\hline \multicolumn{6}{|l|}{ Prior intentions as to relationship } \\
\hline $\begin{array}{l}\text { To marry or live with or was already } \\
\text { married or lived with partner }\end{array}$ & $1.0 \# \#$ & & & $1.0 \# \#$ & \\
\hline $\begin{array}{l}\text { Did not intend to marry or live with, } \\
\text { or wanted to end relationship, or was } \\
\text { not thinking about the future }\end{array}$ & $1.9(1.1-3.3)$ & & & $1.4(0.8-2.6)$ & \\
\hline \multicolumn{6}{|l|}{ Nature of relationship } \\
\hline Occasional & $6.9(2.7-18.1)$ & & & $4.7(1.9-11.3)$ & $5.6(2.2-14.0)$ \\
\hline Steady§§ & 1.0\#\#\# & & & $1.0 \# \#$ & $1.0 \# \#$ \\
\hline
\end{tabular}




\begin{tabular}{|c|c|c|c|c|c|}
\hline \multirow[t]{3}{*}{ Factors } & \multicolumn{5}{|c|}{ OR $(95 \% \mathrm{Cl})$} \\
\hline & \multirow{2}{*}{ Crude } & \multicolumn{4}{|c|}{ Adjusted } \\
\hline & & Level I* & Level II** & Level III ${ }^{\star \star \star}$ & Level IV\# \\
\hline \multicolumn{6}{|l|}{ Age difference of partner } \\
\hline Partner younger or up to a year older & $1.0 \# \#$ & & & $1.0 \# \#$ & $1.0 \# \#$ \\
\hline Partner at least two years older & $2.1(1.1-3.9)$ & & & $2.1(1.0-4.2)$ & $1.8(0.9-3.8)$ \\
\hline \multicolumn{6}{|l|}{$\begin{array}{l}\text { Prior intentions and attitude towards } \\
\text { the pregnancy }\end{array}$} \\
\hline Other situations§§§ & $1.0 \# \#$ & & & $1.0 \# \#$ & \\
\hline $\begin{array}{l}\text { Did not want to get pregnant } \\
\text { and were using contraceptives }\end{array}$ & $1.6(0.9-2.8)$ & & & $1.5(0.8-2.9)$ & \\
\hline \multicolumn{6}{|l|}{ Situation at time of pregnancy } \\
\hline \multicolumn{6}{|l|}{ Age at the time (years) } \\
\hline$\leq 19$ & $3.0(1.7-5.2)$ & & & & $3.1(1.6-6.0)$ \\
\hline$\geq 20$ & $1.0 \# \#$ & & & & $1.0 \# \#$ \\
\hline \multicolumn{6}{|l|}{ Studying at the time } \\
\hline Yes & $1.5(0.8-3.1)$ & & & & $0.9(0.4-2.2)$ \\
\hline No & $1.0 \# \#$ & & & & $1.0 \# \#$ \\
\hline \multicolumn{6}{|l|}{ Working at the time } \\
\hline Yes & $1.0 \# \#$ & & & & $1.0 \# \#$ \\
\hline No & $2.2(1.0-5.3)$ & & & & $2.2(0.8-5.4)$ \\
\hline
\end{tabular}

Source: GRAVAD Research Project, 2002.

* For social/family variables.

** For social/family variables selected at the level and for variables related to mode of sexual debut.

*** For variables selected at levels I and II and for variables related to interaction between partners.

\# For variables selected at levels I, II, and III and for variables related to the young person's situation

at the time of the pregnancy.

\#\# Prevailing minimum wage at the time of the survey.

\#\#\# Reference group.

$\S$ Includes partners like girlfriend, spouse, companion, and other non-occasional.

$\S \S$ Includes partners like that of sexual debut, first girlfriend, other steady, and current partner.

$\S \S \S$ Includes was attempting to get partner pregnant, wanted to get partner pregnant later,

was not thinking about the matter, regardless of contraceptive.

abortion, who tend to be the youngest, poorest, least educated. This is especially so for residents in the city of Salvador, where research in the 1990s showed that this was the largest single cause of maternal mortality 1 . This question merits further investigation in longitudinal studies.

As for possible information biases, since the target population was in its early sexual and reproductive life, it is unlikely that recall problems occurred with such a significant event as abortion. It is possible that some young people may have reported an induced abortion resorting to herbal teas or other self-medication when a pregnancy had not even been confirmed. If this was the case, it is unlikely that the impact was very great.

The central issue is reporting induced abortion as if it were spontaneous, or even omitting it entirely, leading to underestimation of the phenomenon. Even though the younger subjects have greater difficulty in disclosing their sexual debut (and thus its results), the face-toface interview appears to perform better than telephone or other indirect methods 18.

Few studies discuss underreporting according to level of schooling. Among those that were identified, all of which conducted outside of Brazil, controversy persists concerning purportedly higher reporting by more educated individuals 19. If schooling and income influenced disclosure of abortion in the current study, one cannot rule out that part of the differences found between income and schooling strata results from differences in reporting and not in actual occurrence of abortion. However, the results are consistent with the literature on this point.

Validation of information from populationbased studies based on comparison with data from services that perform abortions shows that some degree of non-disclosure always occurs, varying according to cultural, historical, 
and political differences between regions. Although there is no "single and universal" context for disclosing abortion, in face-to-face interviews it is crucial to ensure privacy in a nonstigmatizing, unthreatening environment 20. Information on abortion from surveys, although subject to underreporting, allows investigating characteristics of the individuals, their families, and the context of the abortion, which are scarcely covered in other sources, in addition to comparison with those young men and women who did not report abortions 21 .

Some of the study's methodological options should be discussed. An initial aspect relates to the indicator used to measure the target event. By analyzing abortion as the outcome of the first pregnancy, as measured by the proportion of women who aborted among those who had become pregnant, it was possible to give visibility to another dimension of the phenomenon. This indicator, widely used in the literature $11,12,13$ is not dependent on fertility and is not appropriate for measuring the magnitude of the event, but it is adequate for evaluating the decision vis-à-vis a pregnancy and the differential access to abortion. Other analyses from the GRAVAD Research Project 16 have already highlighted the magnitude of abortion in the target population, measured through the proportion of lifetime abortions, calculated by the number of women who had experienced an abortion some time in life divided by the total number of women, including virgins and nulliparae. The results, in agreement with the literature 1,2 , show that abortion was more frequent among younger, less educated, low-income black or mixed-race women, who also tend to be the ones with the most pregnancies and who resort the most to health services for treating incomplete abortion. This indicator (proportion of lifetime abortion) is dependent on the fertility level, reflecting the higher fertility among low-income young women.

First pregnancy was targeted since it is a reference event for all young women, unlike the first induced abortion, which can have occurred in different gestations, influenced to a varying degree by prior parity.

Abortion did not occur homogeneously in the study population. Although pregnancy is a rarer event among more socially privileged young people, when it does occur they tend to resort to abortion more frequently. This result agrees with other studies $10,12,13,22$ and is consistent with the reasons cited by young people less than 24 years of age for having interrupted a pregnancy (being too young or having study plans or work commitments).
Belonging to more privileged social classes means that schooling fosters better qualifications and access to better jobs, resulting in the phenomenon described as the "prolonging of youth" 14 . Thus, faced with a pregnancy, viewed as an obstacle to future aspirations, the decision to abort appears to be prone to less hesitation. Doubly privileged, these better-off young people not only protect themselves against unpredicted pregnancies, but when they do conceive and opt for abortion, they have access to resources to submit to safer procedures, albeit still illegal.

Young people with upward school mobility have an affirmative personal attitude for overcoming class constraints and show less fertile reproductive behavior (typical of more privileged youth), but lack the same conditions to interrupt pregnancy, and thus submit to the procedure later in pregnancy and under riskier conditions.

For low-income women with less schooling, adolescent pregnancy is more frequent and their choice to continue with the gestation suggests a wager on the birth of a child as a strategy for social belonging and recognition through the motherhood role 23 , or adaptation to their limited opportunities in society 12 . For many young women, already out of school and with no chance at better jobs, motherhood becomes a feasible life project. These findings corroborate other studies in central industrialized countries 24 as well as in Brazil 25 .

Inclusion of males in the study provided a complementary perspective to that of females, normally the ones who are urged to speak about the abortion issue. The young men's importance in reproductive decisions 4,5,6 influences both the status of pregnancy as desired and its outcome 12. However, the results of the interviews with boys should be interpreted with caution, since the models for understanding the phenomenon in relation to them are less well-known and more complex. Interestingly, boys reported higher abortion rates (with their partners), but this result is difficult to compare, since the existing studies only investigate the reliability of abortion reporting by girls.

The higher abortion rate reported by males (with their partners) may indicate less difficulty in disclosing it, not only because of the externality of pregnancy for them, but also because of a symbolic reinforcement of their own fertility and masculinity. It may also reflect imprecision on information concerning pregnancies in their partners 4,5 .

Still, one cannot rule out the occurrence of more abortions in boys (with their partners), due to gender differences in young people's af- 
fective and sexual histories. Male experiences include earlier sexual debut, followed by more frequent occasional partners, involving a higher risk of unplanned pregnancy. The same young man can get various partners pregnant simultaneously, which is consistent with Brazilian sexual culture (granting males this prerogative), especially among low-income communities and those with more traditional gender relations. The boys interviewed here do not coincide precisely with the group of potential partners of the girls in the study, who relate to men from a broader age range, including not only these boys but also older men, who are already working and have better chances of consolidating a relationship.

The factors associated with abortion in the first pregnancy are located at various levels, with similarities and differences between females and males. For both, in addition to the importance of schooling, the nature and degree of legitimacy of the relationship with the partner are elements that frame the desirable scenario for the arrival of a child. The odds of an abortion increase for girls in the case of an unconsolidated or unsteady relationship or one in crisis, and for boys in case of a pregnancy with an occasional partner.

Age at sexual debut was not statistically associated with abortion for either males or females, contradicting the perspective that early initiation necessarily predicts undesirable and negative outcomes 26. Parents' separation, often incriminated as predictive of such behaviors, was also not relevant according to our results. Loaded with moral values, this variable is based on a concept of nuclear family which does not correspond to the multiplicity of existing family arrangements in Brazil. In the current study, relational dimensions of family, such as talking with parents about pregnancy and contraceptive methods, were more important than family structure.

Contraceptive use at the time of conception was not associated with pregnancy outcome. Young people's relationship to contraception deserves further investigation to unveil the more immediate determinants of these practices. Despite widespread awareness of contraceptives, mistaken notions of conception and contraception persist, partially explaining the methods' limited effectiveness 27 . Added to the above are problems of access to public health services, the limited array of inputs, lack of continuity in supply, and insufficient number of places organized to serve youth.

The study showed lower reporting of abortion among Pentecostal men, consistent with their more conservative sexual values, attitudes, and practices 16 . Unlike females, males who were still adolescents at the time of the partner's pregnancy showed a higher abortion rate. For these boys, young age probably meant less capacity to meet the demands of a new family nucleus.

The differences between cities, with higher percentages of abortion in the first pregnancy in Salvador and lower in Porto Alegre, highlighted the need for further investigation. Such patterns may combine socioeconomic factors and cultural distinctions between the cities, leading to differences in availability and access by youth to reproductive health services. These cities represent quite distinct scenarios for youth socialization, modes of sexual debut, and affective histories. Contrary to cultural stereotypes, youth in Porto Alegre have earlier sexual debut but report less pregnancy and abortion, as compared to Salvador, where sexual debut comes later but pregnancy and induced abortion are more prevalent 16 .

Previous analyses in the GRAVAD Research Project 28 have shown that the majority of girls did not intend to become pregnant, even though they were not using contraceptives; if this is true, it appears relevant to describe the first reproductive episode as "unpredicted". This notion, as postulated by some authors 12 , encompasses different representations of pregnancy, unlike the more commonly used terms such as "unplanned" or "unwanted", which fail to express the possible ambivalence towards the desire for a child.

Understanding the processes leading up to the decision to abort will be the object of the next stage in the data analysis. Analysis of the interviews from the qualitative stage of the GRAVAD Research Project 5 already showed that in the face of unpredicted pregnancies, abortion is a plausible alternative with a continuum ranging from simply considering the procedure to an unsuccessful attempt or a completed abortion, even when the latter is not always unequivocally desired.

Discussion of the theme should not overlook the unique Brazilian situation of extreme inequality and social exclusion of a large segment of the population, the effects of which are particularly harsh for youth. This social heterogeneity shapes distinct possibilities for youth of different social origins, with diverse family arrangements and sociability networks, material living conditions, school attainment, and work market prospects and actual work participation. In these multiple life histories, plans for married life and motherhood/fatherhood 
assume specific places and meanings. We thus conclude that given an unpredicted pregnancy, these determinants are certain to present the youth with distinct possibilities for dealing with the decision concerning a possible abortion.

It is up to the state and government administrations to implement inter-sector measures to ensure young people's sexual and reproductive rights. This means guaranteeing their access to quality education and health services,

\section{Resumo}

Esta pesquisa objetivou identificar os fatores associados ao aborto provocado na primeira gravidez das mulheres e na primeira vez que os homens engravidaram uma parceira. Trata-se de inquérito domiciliar por meio de entrevista face a face de uma amostra probabilística, em três estágios, de 4.634 jovens, entre 18 e 24 anos, residentes em Salvador, Rio de Janeiro e Porto Alegre, Brasil. Utilizou-se análise de regressão logística, com estratégia hierarquizada para entrada das variáveis no modelo. O aborto foi o desfecho da primeira gravidez referido por 16,7\% das mulheres $e$ 45,9\% dos homens, relativamente a suas parceiras. Entre os fatores associados ao aborto, destacam-se a escolaridade mais elevada dos jovens e a natureza eventual da relação com o/a parceirola dessa gravidez. A inclusão dos homens na pesquisa traz novos elementos para compreensão do fenômeno do aborto, inserindo as questões de gênero na discussão do tema. Recomenda-se um maior investimento público de modo a garantir aos jovens acesso a informações e recursos para realizarem seus projetos reprodutivos de forma segura e saudável, respeitando seus direitos sexuais e reprodutivos.

Aborto Induzido; Identidade de Gênero; Sexualidade

\section{Contributors}

G. M. S. Menezes contributed with the data analysis and interpretation and drafting of the article. E. M. L. Aquino contributed with the study conceptualization, definition of strategies and data collection techniques, research instrument design, and coordination of the research in Salvador, including selection and training of the team, overall fieldwork supervision, construction of the database, data analysis and interpretation, and review of the text. D. O. Silva collaborated with the statistical analyses. providing them with the necessary information and means to experience their sexuality in a responsible and safe way, specifically as regards contraceptive methods and STD prevention, above all considering the current scenario with the AIDS epidemic. The issue is to be able to avoid unpredicted pregnancies, but when they occur, to have the necessary autonomy to make choices and enjoy health, free of risks.

\section{Acknowledgments}

The study Teenage Pregnancy: A Multi-center Study on Youth, Sexuality, and Reproduction in Brazil (GRAVAD Research Project) was originally prepared by Maria Luiza Heilborn (Instituto de Medicina Social, Universidade do Estado do Rio de Janeiro, Brazil - IMS/UERJ), Michel Bozon (Institut National d'Études Démographiques, France - INED), Estela M. L. Aquino (Programa Integrado de Pesquisa e Cooperação Técnica em Gênero e Saúde/Universidade Federal da Bahia, Brazil MUSA/UFBA), and Daniela Knauth (Núcleo de Antropologia do Corpo e Saúde/Universidade Federal do Rio Grande do Sul, Brazil - NUPACS/UFRGS). The study was carried out by three research centers, the Program on Gender, Sexuality, and Health (IMS/UERJ), the MUSA/UFBA, and the NUPACS/UFRGS. The main results of the survey have been published in the book O Aprendizado da Sexualidade: Reprodução e Trajetórias Sociais de Jovens Brasileiros (Rio de Janeiro: Garamond; 2006), which includes detailed information on the composition of the research team. The authors further acknowledge the financial support from the Ford Foundation (Fundação Ford), the Brazilian National Research Council (Conselho Nacional de Desenvolvimento Científico e Tecnológico), and the Coordinating Body for Training University Level Personnel (Coordenação de Aperfeiçoamento de Pessoal de Nível Superior), through their research grant programs. 


\section{References}

1. Departamento de Ações Programáticas Estratégicas, Secretaria de Atenção à Saúde. Atenção humanizada ao abortamento: norma técnica. Brasília: Ministério da Saúde; 2005.

2. Fonseca W, Misago C, Correia LC, Parente JAM, Oliveira FCI. Determinantes do aborto provocado entre mulheres admitidas em hospitais em localidade da região Nordeste do Brasil. Rev Saúde Pública 1996; 30:13-8.

3. Costa RG, Hardy E, Osis MJD, Faúndes A. A decisão de abortar: processos e sentimentos envolvidos. Cad Saúde Pública 1995; 11:97-105.

4. Ramirez-Galvez MC. Os impasses do corpo: ausências e preeminências de homens e mulheres no caso do aborto voluntário [Dissertação de Mestrado]. Campinas: Departamento de Antropologia Social, Universidade Estadual de Campinas; 1999.

5. Peres SO. Aborto e juventude: um horizonte de possibilidades diante da gravidez na adolescência [Tese de Doutorado]. Rio de Janeiro: Instituto de Medicina Social, Universidade Estadual do Rio de Janeiro; 2003.

6. Duarte G. Contracepção e aborto: perspectiva masculina [Dissertação de Mestrado]. São Paulo: Departamento de Saúde Materno-Infantil, Faculdade de Saúde Pública, Universidade de São Paulo; 2000.

7. Silva RS. O uso da Técnica de Resposta ao Azar (TRA) na caracterização do aborto ilegal. Revista Brasileira de Estudos Populacionais 1993; 10:41-56.

8. Osis MJD, Hardy E, Faúndes A, Rodrigues T. Dificuldades para obter informações da população de mulheres sobre aborto ilegal. Rev Saúde Pública $1996 ; 30: 444-51$.

9. Olinto MTA. Aborto induzido: freqüência, fatores de risco e preditores [Tese de Doutorado]. Campinas: Faculdade de Ciências Médicas, Universidade Estadual de Campinas; 1998.

10. The Alan Guttmacher Institute. Sharing responsibility: women, society \& abortion worldwide. New York: The Alan Guttmacher Institute; 1999.

11. Bankole A, Singh S, Haas Y. Reasons why women have induced abortions: evidence from 27 countries. Int Fam Plan Perspect 1998; 24:117-27.

12. Bajos N, Ferrand M; L'Équipe GINÊ. De la contraception à l'avortement: sociologie des grossesses non prévues. Paris: Éditions Inserm; 2002.

13. Sihvo S, Bajos N, Ducot B, Kaminski M. Women's life cycle and abortion decision in unintended pregnancies. J Epidemiol Community Health 2003; 57:601-5.

14. Heilborn ML, Salem T, Rohden F, Brandão E, Knauth D, Victora C, et al. Aproximações sócioantropológicas sobre a gravidez na adolescência. Horizontes Antropológicos 2002; 17:13-45.
15. World Health Organization. Young people's health: a challenge for society. Geneva: World Health Organization; 1986. (WHO Technical Report Series, 731).

16. Heilborn ML, Aquino EML, Knauth DR, Bozon M. organizadores. O aprendizado da sexualidade: um estudo sobre reprodução e trajetórias sociais de jovens brasileiros. Rio de Janeiro: Garamond; no prelo.

17. Bajos N, Marquet J. Research on HIV sexual risk: Social relations-based approach in a cross-cultural perspective. Soc Sci Med 2000; 50:1533-46.

18. Smith LB, Adler NE, Tschman JM. Underreporting sensitive behaviors: the case of young women's willingness to report abortion. Health Psychol 1999; 18:37-43.

19. Udry RJ, Gaughan M, Schwingl PJ, Berg BJ. A medical record linkage analysis of abortion underreporting. Fam Plan Perspect 1996; 28:228-31

20. Huntington D, Mensch B, Miller VC. Survey questions for the measurement of induced abortion. Stud Fam Plann 1996; 27:155-61.

21. Michael RT. Abortion decisions in the United States. In: Laumann EO, Michael RT, editors. Sex, love and health in America: private choices and public polices. Chicago: University of Chicago Press; 2001. p. 377-438.

22. Pirotta KCM, Schor N. Intenções reprodutivas e práticas de regulação da fecundidade entre universitários. Rev Saúde Pública 2004; 38:495-502.

23. Le Van C. Les grossesses à l'adolescence. Normes sociales, réalités vécues. Paris: L'Harmattan; 1998.

24. Singh S, Darroch JE, Frost JJ, Study Team. Socioeconomic disadvantage and adolescent women's sexual and reproductive behavior: the case of five developed countries. Fam Plann Perspect 2003; 33:251-8.

25. Gupta M, Leite IC. Adolescent fertility behaviour: trends and determinants in Northeastern Brazil. Int Fam Plann Perspect 1999; 25:125-30.

26. Miller BC, Benson B, Galbraith, KA. Family Relationships and adolescent pregnancy risk: a research synthesis. Dev Rev 2001, 21:38.

27. Almeida MCC, Aquino EM, Gaffikin L, Magnani RJ. Uso de contracepção por adolescentes de escolas públicas na Bahia. Rev Saúde Pública 2003; 37:566-75.

28. Aquino EML, Heilborn ML, Knauth D, Bozon M, Almeida MC, Araújo J, et al. Adolescência e reprodução no Brasil: a heterogeneidade dos perfis sociais. Cad Saúde Pública 2003; 19 Suppl 2:S377-88.

Submitted on 29/Sep/2005

Final version resubmitted on 16/Jan/2006

Approved on 19/Jan/2006 